77. ガラス線量計による実効エネルギー推定

Estimation of effective energy with glass dosimeter

\author{
藤田保健衛生大学衛生学部 \\ 藤田保健衛生大学医学部 \\ 東海医療技術専門学校
}

\author{
○藤井茂久、鈴木 昇一、折戸武郎 \\ (Shigehisa Fujii) (Syouichi Suzuki) (Takeo Orito) \\ 浅田 恭生 \\ (Yasuki Asada) \\ 嶋崎 宏紀、稲垣 信司、山口 幸三 \\ (Hiroki Shimazaki) (Shinji Inagakj) (Kouzou Yamaguchi)
}

1.目的

ガラス線量計は、低エネルギー光子のエネルギー推定ができるため、診断領域X線での応用が期待され ている。しかし、従来は線質指標 (Q1)0.8 程度のX線によって校正されていたため、QIが 0.4 程度の診断 領域X線に対して実効エネルギー推定を行うと高めに評価される傾向にあった。そこで、我々は診断領域 $\mathrm{X}$ 線用の校正条件を考案し、発生方式の違いによる実効エネルギ一の精度について検討したので報告する。

2. 方法

インバータ式、三相 12 ピーク形、単相 2 ピーク形X線高電圧発生装置を用いて、管電圧 $50,70,90,11$ OKVにて吸収線量と実効エネルギーを测定した。幾何学的配置はSID=1m とし、線量計の位置は撮影台よ り高さ $3 \mathrm{~cm}$ の位置とし、照射野は線量計の高さで $10 \mathrm{~cm} \times 10 \mathrm{~cm}$ とした。吸収線量は、ガラス線量計（東 芝硝子 SC-1) と $0.2 \mathrm{cc}$ シャロー型電離箱を用いて、置換法にて測定した。次に、実効エネルギーはガラス 線量計とX線アナライザ (化成オプトニクス MODEL 100) で測定した。ガラス線量計では、新しく考案した 2 つの校正条件にて実効エネルギーを推定した。

\title{
3. 結果および考察
}

診断領域X線用として考案したガラス線量計のエネルギー校正条件を表 1 に示す。校正条件(1)は、総

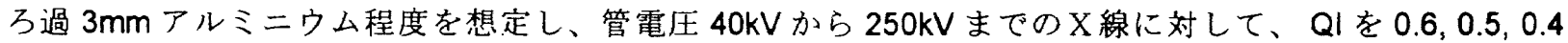
と変化させた条件とした。校正条件(2)は(1)笚純化したもので、QIを 0.4 に統一した校正条件とした。 インバータ式では、ガラス線量計の吸収線量は、電離箱線量計と比べて低值を示し、最大で $15 \%$ の誤 差が、実効エネルギーは、X線アナライザと比べて最大 $2 \mathrm{keV} の$ 誤差が認められた（表 2 ）。三相 12 ピ

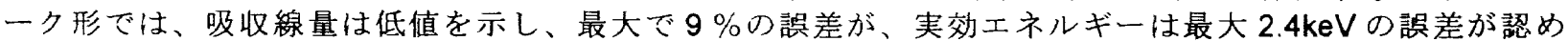
られた (表 3)。単相 2 ピーク形では、吸収線量は他の 2 方式と同様に低值を示し、最大で $9 \%$ 埕差 が、実効エネルギーは最大 $2.7 \mathrm{keV} の$ 誤差が認められた（表 4 ）。

以上より、ガラス線量計の吸収線量の精度は土 $20 \%$ あるので、各発生方式とも、ガラス線量計と電 離箱線量計の吸収線量は一致していると考えられる。X線アナライザの実効エネルギ一の精度は土 $3 \mathrm{keV}$ であるので、ガラス線量計の校正条件(1)、(2)にて推定した実効エネルギーとX線アナライザの值は一致し ていると考えられる。また、ガラス線量計の精度に関して、発生方式による差は認められなかった。

4.まとめ

1) ガラス線量計から推定した実効エネルギーは、最大 $2.7 \mathrm{keV} の$ 誤差でX線アナライザの值と一致した。 また、ガラス線量計の精度に関して、発生方式による差は認められなかった。2)ガラス線量計で得られ た吸収線量は、電離箱線量計と比べて最大で $10 \%$ の誤差で一致し、低い值を示す傾向が認められた。3) ガラス線量計は実際の診断領域X線の線質、つまり、QIを0.4、または $0.4 〜 0.6$ の校正条件でエネルギ 一校正を行えは、精度の高いエネルギ一推定ができるので、患者被曝線量測定に有用であると考えられた。

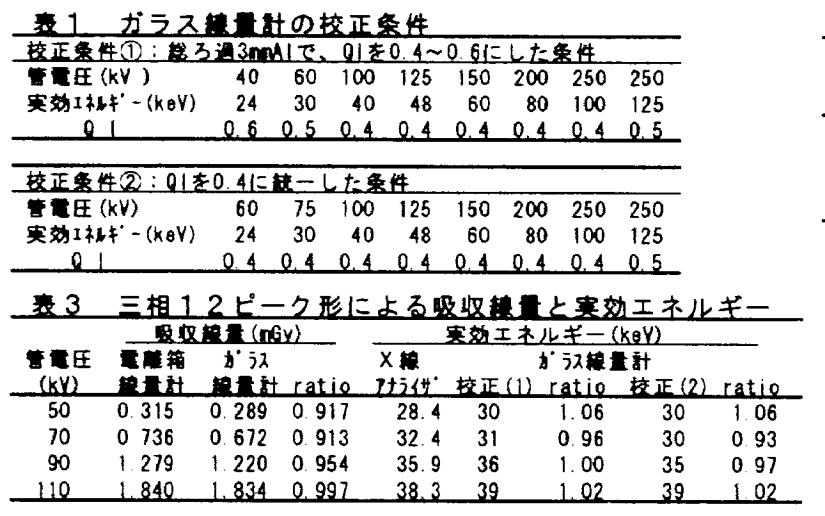

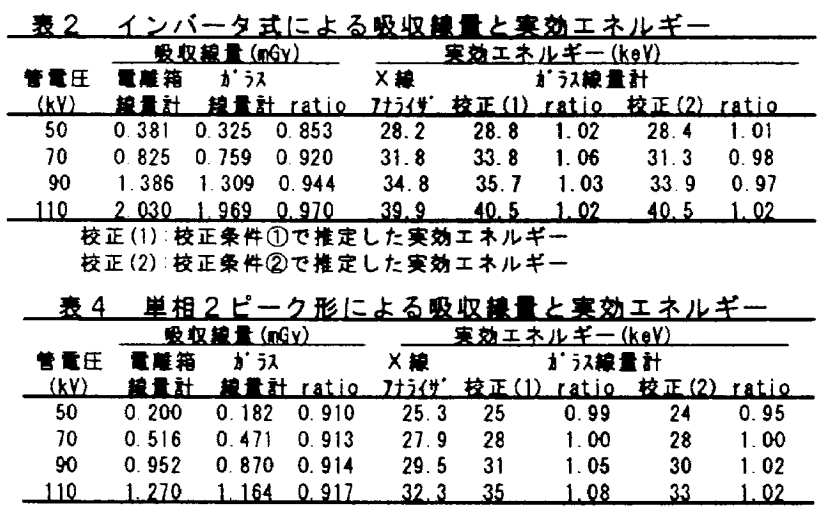

